\title{
From the latent to emergent entrepreneurship: the knowledge spillover construction circle
}

Article

Accepted Version

Caizza, R., Belitski, M. and Audretsch, D. B. (2020) From the latent to emergent entrepreneurship: the knowledge spillover construction circle. Journal of Technology Transfer, 45 (3). pp. 694-704. ISSN 1573-7047 doi: https://doi.org/10.1007/s10961019-09719-y Available at https://centaur.reading.ac.uk/83916/

It is advisable to refer to the publisher's version if you intend to cite from the work. See Guidance on citing.

To link to this article DOI: http://dx.doi.org/10.1007/s10961-019-09719-y

Publisher: Springer

All outputs in CentAUR are protected by Intellectual Property Rights law, including copyright law. Copyright and IPR is retained by the creators or other copyright holders. Terms and conditions for use of this material are defined in the End User Agreement.

www.reading.ac.uk/centaur 
Central Archive at the University of Reading

Reading's research outputs online 


\title{
From latent to emergent entrepreneurship: The knowledge spillover construction circle
}

\author{
Rosa Caiazza \\ Parthenope University of Naples, Naples, Italy \\ Maksim Belitski \\ Henley Business School, University of Reading, Henley-on-Thames, UK \\ David B. Audretsch
}

School of Public and Environmental Afairs of Indiana University Bloomington, Bloomington, IN, USA

\begin{abstract}
The process that turns knowledge into innovation is highly ambiguous and complex. This study merges economic and management perspectives to extend the knowledge spillover theory of entrepreneurship in explaining how the knowledge spillover construction circle works. At this aim it introduces the model of 'latent and emergent entrepreneurship' evidencing the strategic role of the entrepreneur in each step of the process that goes from the research of new knowledge to its commercialization.

Keywords Entrepreneurship · Knowledge spillover · Construction circle $\cdot$ System of innovation JEL Classifcation: M10 - M15
\end{abstract}

\section{Introduction}

Main economic theories provide the theoretical framework for analyzing drivers of firm performance and regional economic development. While classical, neoclassical and Keynesian perspectives are focused on capital and labor, Schumpeter evidences innovation as a driver for economic growth and creativity (Schumpeter, 1934). With the concept of creative destruction, Schumpeter offers that introduction and diffusion of new knowledge could replace the obsolete products driving the 
development of the whole economy, by increasing the competitiveness of new entrants and incumbent firms (Fritsch and Mueller, 2008). The value created by innovators exceeds that contributed by incumbents generating a "Darwinian-type" process by which new products replace the previous ones (Audretsch and Fritsch, 1996; Fritsch and Mueller, 2004). Despite Schumpeter (1934) recognizes the role of innovator in taking opportunities for starting the process of creative destruction of obsolete products, he is silent on describing where these opportunities come from. Entrepreneurship activity plays an important role in commercialization of newly available knowledge in the market, for example via spin-offs (Markuerkiaga, Caiazza, Igartua, Errasti, 2016, Caiazza, 2016a). It serves as an endogenous response to opportunities created by investments in knowledge, but not yet commercialized as the value of new product is often uncertain (Agarwal et al. 2004, 2007, 2010; Caiazza, 2017). However entrepreneurship does not occurs in a vacuum, its an activity which transfers an identified knowledge into realized and practical market action under high uncertainty (Kirzner, 1999).

This study aims at developing and theoretically describing the concept of the knowledge spillover of creative construction cycle, by demonstrating that identified action leads to a development of the latent entrepreneurs and later based on knowledge generated by others to identify, access, adapt and allocate it to market needs, emerges as the emergent entrepreneur (Agarwal et al. 2007). This study describes the four steps of such process within the knowledge spillover of strategic entrepreneurship effect, when the intended action is realized in the market.

This study contributes to creative construction literature (Schumpeter, 1934) and knowledge spillover of strategic entrepreneurship literature (Agarwal et al. 2007, 2010) by demonstrating the process how entrepreneurship emerges (Audretsch and Keilbach, 2007) from its latent form to emergent and market innovation (Caiazza et al., 2016b). In recognizing several forms of entrepreneurship, this study contributes to strategic entrepreneurship literature by offering a four-step process theoretical framework where latent and emergent entrepreneurship activity is important as an economic agent able to exercises judgment under uncertainty for pursuing opportunities to start a new firm (Caiazza, 
et al., 2015, Caiazza, 2014). The process was first mentioned by Kirzner (1999) as knowledge exploitation and dis-equilibrium of the market by entrepreneurs.

Our finding demonstrate that the latent and emergent entrepreneurship are closely connected and may be used by scholars, policy makers and firms to facilitate the process of creative construction and destruction. The remainder of the paper is as follows. Section 2 revises the economic to management theories on entrepreneurship. Section 3 discusses the process of the knowledge spillover construction circle which demonstrates how latent entrepreneurship transfers into the emergent type. It illustrates the mechanism of four steps of the process. Having discussed the model of latent and emergent entrepreneurship we describe how these types of entrepreneurship contribute to creative construction and destruction in section 4 . Section 5 concludes and discusses this new framework.

\section{From economic to management theory on entrepreneurship}

The knowledge spillover theory of entrepreneurship (KSTE) evidences that such opportunities consist of a set of ideas endogenously created by investments in new knowledge that enable the creation of future products in the absence of current markets. Such investments on one side contribute to technological advancement of firms that invest in research and on the other side create opportunities for both incumbents already operating on the market and for start-up that aim to develop a new market. Investments in new knowledge create innovative opportunities for three kinds of economic agents: firms that invest in research, incumbent firms and new entrants. The ability of one of them to develop such opportunities let it to assume the role of innovator.

Existing firms that invest in research of new knowledge not automatically become innovators because the uncertainty of the process of commercialization of original knowledge (Alvarez and Barney, 2005). Costs due to knowledge's asymmetries and frictions come from institutions impose what Audretsch and Keilbach (2007) and Acs et al. (1994) define as the knowledge filter. The knowledge filter depends on basic conditions of knowledge and represents the gap between new knowledge and its commercialization. Overcoming such filter firms that invest in research become able to develop 
new knowledge commercial potential becoming innovators. On the contrary, if knowledge filter makes firms that invest in research unable to commercialize its knowledge, it can create some innovative opportunities for incumbents or new entrants. Innovators are economic agents able to recognize such opportunities, overcome knowledge filter and take the risk to turn new knowledge in innovations. The exploitation of new opportunities created by other firms gives rise to innovative activity of incumbents that develop innovations. Such innovations depend on incumbents' ability to take economic benefits from knowledge-spillover (Cohen and Levinthal, 1989; George ad Zahra, 2002). If even incumbents are not able to commercialize knowledge, this creates an opportunity of knowledge commercialization through new business activity and spin-offs. Thus the exploitation of new opportunities created by incumbents gives rise to entrepreneurial activity of new entrants that create start-up to develop innovations (Acs, et al. 1994).

The knowledge spillover theory of entrepreneurship evidences the role of entrepreneurship as catalyst that turns knowledge spillovers into creativity (Audretsch and Belitski, 2013) and innovation (Audretsch and Caiazza, 2016). It evidences the role of economic agents which bring innovation to market and facilitate economic growth (Caiazza, 2015).

Knowledge search becomes an important boundary condition for entrepreneurs and other entrepreneurship ecosystem agents (Audtretsch and Belitski, 2017) to pursue their individual interests, while creating a collective conditions (Wennekers and Thurik, 1999 Wiklund, et al., 2011) to support the whole entrepreneurship ecosystem (Stam, 2018) as well as creates a process of knowledge transformation (Spigel and Harrison, 2018).

\section{From latent to emergent entrepreneurship : the knowledge spillover construction circle}

Combining the assumptions of Audretsch and Keilbach (2007) on the knowledge spillover theory of entrepreneurship with the managerial perspectives of Porter (1996) and Mintzberg (1978) concerning strategy we introduce the model of latent and emergent entrepreneurship. This model aims to explain the process of new firm creation from knowledge developed by another one because of the strategic 
action of the entrepreneur. At this aim we starts from the concept of strategic entrepreneurship that highlights the complementarities within entrepreneurship and strategy (Kuratko and Audretsch, 2009, Ireland, Hitt and Sirmon, 2003). The entrepreneurship concerns the process of designing, launching and running a new business at the aim to offer a new product, process or service (Bruton, et al., 2010). Thus, entrepreneurship revolves around the recognition of innovative opportunities that have to be developed in a strategic way (Bhide, 1994). The strategy concerns the most relevant managerial decisions that influence firm ability to create value. Managerial literature classifies strategies as either deliberate or emergent. A strategy can be described as deliberate where the collective vision, goals and intention of a firm is articulated as broadly as possible in order to realize a given outcome. On the other hand, a strategy can be described as emergent where consistencies arise in the actions of a firm over a period of time, even though the adoption of such actions was never explicitly intended.

According to such definitions a deliberate form of entrepreneurship is fully implemented when the realized entrepreneurship is equal to intended entrepreneurship. In this case, a focal firm realizes a research activity aimed to create new knowledge in order to develop a new firm that commercializes this innovation (Caiazza et al., 2016b). When intentions are realized exactly as intended this process of deliberate entrepreneurship leads to a spin-off of a new firm from the focal one (Shane and Venkataraman, 2000). This process requires that the entrepreneur belongs to the focal firm and uses knowledge produced within its original firm for creating a new firm with the explicit aim to commercialize knowledge. When knowledge generated in an establishing a company, intended entrepreneurship activity, also known as latent entrepreneurship converges into emergent entrepreneurship. The important component in it is the process of deliberate commercialization of knowledge that requires both strategic and entrepreneurial capabilities.

The mechanism of transformation of latent entrepreneurship into an emergent is as follows.

A latent entrepreneur working for a firm realizes an investment in knowledge may bring a considerable pay-offs and considers the expected value of a new idea. The value may not be sufficiently attractive to an incumbent form, however is attractive enough for a latent entrepreneur. 
The knowledge filter in an incumbent firm prevents a latent entrepreneur from pursuing its aim of commercialization of a new knowledge. Inability of incumbent firms to penetrate the knowledge filter (Audretsch et al. 2006) creates entrepreneurial opportunities for others able to exploit knowledge spillovers. A latent form of entrepreneurship exists until no one is able to use knowledge spilling out its original source to implement entrepreneurial projects and introduce an innovation on the market. However, when someone exploits knowledge spillovers to start a new firm emerges from its latent form and is known as emergent entrepreneurship. This may not be the end of the emergent entrepreneurship journay as more efforts should be taken to sustain and develop the idea, which is further operationalized by establishing a new venture.

As such, realized opportunity is not a deliberate project based on knowledge, but an emerging process where an emergent entrepreneur is a conduit of knowledge-spillover to customer. The process that leads latent entrepreneurship based on knowledge generated by others to identify, access, adapt and allocate it to market needs, emerges as the knowledge spillover of strategic entrepreneurship (Agarwal et al. 2007, 2010). It requires entrepreneur's ability to let emerge latent form of entrepreneurship into exploitation of opportunities and emergence of the knowledge spillover. Figure 1 illustrates the knowledge spillover of strategic entrepreneurship effect when the intended entrepreneur realized its market opportunities

Figure 1. The knowledge spillover creative construction circle: from intended to realized action

$\begin{array}{lll}\begin{array}{l}\text { Knowledge } \\ \text { created }\end{array} & \begin{array}{l}\text { Intended } \\ \text { action }\end{array} & \text { Deliberate process of entrepreneurship } \rightarrow \text { Realized action } \\ \text { Market } \\ \text { commercialization }\end{array}$


Knowledge spillover strategic

entrepreneurship

Source: Authors

Our model starts from an intended action by a would-be entrepreneur. It considers a plan to launch a new business in order to introduce new knowledge to market. Realized action will be the final objective when the knowledge is monetized. A correct implementation of a plan is required and consists of four subsequent steps. Step one,

as deliberate action by an entrepreneur the unrealized opportunity turns into the latent form of entrepreneurship where market search and adaptation of knowledge to market takes place. . This step is also known as unrealized entrepreneurship. At this step the knowledge may remain uncommercialized as a result of market uncertainty, high risks, lack of skills and capabilities of an entrepreneur.

Step 2 is the transition between the unrealized to latent entrepreneurship where opportunities are identified but not yet marketed. Step three is Emergent entrepreneurship when the action is taken to bring he knowledge in the market in a form of a product or services. Its likely that at this stage entrepreneurs will apply for finance, build partnerships and enhance product development along with market adjustment. This is most important stage of the knowledge spillover strategically. Step for knowledge is in the market in a form of a product and service and the market is growing (realized action).

Given market uncertainty when first implementing the product, the strategic approach to the knowledge spillover may become the dominant model (Audretsch and Lehmann, 2016). Knowledge is constantly improving and firms cannot stop analyzing, assessing, and planning to keep up new knowledge. Thus firms involved in research activity for introducing new knowledge generally are not able to implement a deliberate process of entrepreneurship to realize their original idea (Oldroyd, et al., 2010). Intended action of entrepreneurs is generally transformed in unrealized to latent, emergent 
and realized action by entrepreneurs. However, new knowledge, even if doesn't support a deliberate process of entrepreneurship, creates an abundance of potential innovative opportunities leading to knowledge spillover to other economic agents (Audretsch and Feldman, 1994) and further exploitation of latent opportunities created by the fact of knowledge presence.

New entrants perceiving unexploited opportunities created by other firms' knowledge can transfer the latent form of entrepreneurship into starting-up and growing new business (emerging form). Entrants that successfully engage into an entrepreneurial activity turn latent entrepreneurship in an emergent one (Caiazza and Stanton, 2016, Caiazza, 2016b). Through a process of emergent entrepreneurship, knowledge spillovers are used to create a new firm able to introduce innovation on the market (Parker, 2009, 2010). The entrepreneur that will fare the best most likely are going to be those that learn how to achieve and use new knowledge to implement emergent entrepreneurship process for innovation (Wennekers, et al., 2005).

\section{From a creative destruction to creative construction}

Regions that support firms' investments in knowledge are likely to have an abundance of knowledge (Gambardella and Giarratana, 2010) and an ability top spillover new knowledge (Agarwal et al. 2007). Knowledge creates entrepreneurial opportunities that give rise to new idea generation and some pre-mature forms of latent opportunities. Exploiting knowledge spillovers let latent form of entrepreneurship to emerge. Consequently, regions with high knowledge investments have high level of knowledge spillovers that lead to more start-up that introduce innovations on the markets (Acs and Storey, 2004). In turn, entrepreneurship serves as an important source of economic growth that provides new resource to invest in research, innovation and entrepreneurship (Autio, Kenney, Mustar, Siegel and Wright, 2014). This creative construction circle is based on the idea that knowledge creates opportunities that can lead to innovations and entrepreneurships that support economic development of a local innovation system (Agarwal et al., 2007). This circle is reinforced if innovations introduced in the market are diffused from the first innovator to different adopters (Almeida and Kogut, 1999). 
Without diffusion of new knowledge, an innovation will have no economic impact. How does this happen?

Innovators can push and pull new to market products through several activities (Stuart and Sorenson, 2003). Specifically, they can develop complementary products able to support the original innovation and diffuse information concerning innovation potential uses (Liu, Wright, Filatotchev, Dai and Lu, 2010). Also adopters can implement strategies to reduce switching costs and risks in adopting innovation (Romer, 1990). Specifically, they can change their previous network of suppliers and modify established processes in adopting innovation (Cohen and Levinthal, 1990). Over time, diffusion of innovation among several adopters allows for efficient reutilization of knowledge processes and reduce uncertainty and risk (Fleming, 2001). Thus, a new technological path can come out of a system reinforcing the virtuous circle of creative construction that supports economic growth (Acs and Varga, 2005) and supports the knowledge spillover of strategic entrepreneurship mechanism (Agarwal et al. 2007).

Policy-makers and companies can support the process of creative construction through public and private measures (Ahuja and Katila, 2001). The role of public policy is to facilitate knowledge creation, to encourage agents of change to introduce innovations and start new firms (Audretsch, 1995). By creation new knowledge incumbent firms may be extinguished.

The relationship between new businesses and market development is quite complex. Analyzing this relationship requires a comprehensive approach that should include more than the development of new knowledge is related to both creation of jobs, growth, but also the related supply-side effects. Innovation represent an entry of new ideas into the market and are therefore an essential element in emergent entrepreneurship. One contribution that new businesses make to market is found in the evolution of the species, which may be labelled as the direct eff ect of new capacities. New knowledge may push exit as a result from the entry of new emergent entrepreneurs. First, there are new businesses that fail to be sufficiently competitive and thus have to leave the market after some time. Second, there is the crowding out of incumbents by their new competitors, which leads to declining market 
shares of incumbents and exit. The creative construction will be followed by creative destruction, while knowledge spillovers that are rather indirect will result from intensified competition and new knowledge. These may facilitate new entry and pertain to the supply-side of the market (Fritsch and Mueller, 2004) where new firms spill over. If this virtuous circle is supported from all the actors and institutions of a region it can turn a region in a local innovation system (Van Stel, Carree and Thurik, 2005) and create an efficient framework conditions for the entrepreneurship[ ecosystem (Audretsch and Belitski, 2017).

\section{Discussion and conclusions}

This study reconciles the economics and managerial perspectives on the debate involving knowledge, innovation, entrepreneurship and economic growth. It offers a theoretical framework of a knowledge spillover construction circle, enabling the deliberate process of entrepreneurship and knowledge exploitation from the latent to the emergent type of entrepreneurship. The framework fully supports the knowledge spillover of strategic entrepreneurship (Agarwal et al., 2010) and the Schumpeterian vision of an entrepreneur (Schumpeter, 1934).

Schumpeter described the tension between innovations of new firms and selection pressures on existing firms (Schumpeter, 1934). However, Schumpeter's perspective is silent with regard to the source of innovative opportunities and the process (Kirzner, 1999). The knowledge spillover construction circle framework evidences that such opportunities consist of a set of ideas endogenously created by investments and realized in the market, while incumbent firms are likely to be the one to share the market with new emergent entrepreneurs. As new knowledge spills out, the original sources of knowledge enable entrepreneurs to introduce innovations and effectuate the market destruction.

Therefore, entrepreneurs create change from an unrealized opportunity through their entrepreneurial actions in response to their decision under uncertainty about a possible opportunity for profit. Thus entrepreneurial action depends on the degree of uncertainty experienced in entrepreneur decisions 
(Fritsch, 1997) and the response of incumbents, initially to penetrate the knowledge filter (Audretsch et al., 2006) or then further compete in the maket and exit (Fritsch and Mueller, 2004, 2008).

Despite of more individual agents are exposed to the same new knowledge only few of them have the capability to let emerge latent forms of entrepreneurship. Accordingly, entrepreneur is conceptualized in terms of his strategic and entrepreneurial capability to use knowledge spillovers for creating new firms. In this way, the model of latent and emergent entrepreneurship overcomes Schumpeterian consideration of innovation as driver of economic growth because it recognizes the role of entrepreneur as individual agent that starts such process. In the knowledge spillover construction circle perspective, entrepreneur is the driving force of innovation upon which economic development and growth.

In the theory of creative destruction, Schumpeter (1934) was silent about strategic capabilities of entrepreneurs. New firms infused with entrepreneurial spirit would displace the tired old incumbents, ultimately leading to vigorous innovative activity that in turn would generate a higher degree of economic growth. Strategic capabilities synthesize the intuition and creativity of an entrepreneur into a vision for the future that are required to complete construction circle process of the four steps to finally realize the entrepreneurial action.

Thus, managerial perspective extends and complete the economic assumptions made by the knowledge spillover construction circle on the role of entrepreneur in the process that lead knowledge to be turned into innovation for the economic growth (Audretsch, 2007).

Thus, creative construction is a process through which entrepreneurs benefit from knowledge created by existing firms to realize innovation that do not lead to destruction of incumbent firms. This type of process has been put forward by Schumpeter (1934) concept of 'creative destruction' and by Marshall's (1920) analogy of a forest in which the old trees must fall to give way to the new ones. In this process, knowledge management and strategic entrepreneurship have been identified as critical for firms, industries, regions, and economies growth. Managerial and strategic skills are required to facilitate the action by entrepreneur, when knowledge is not only further diffused, but also developed 
with incumbents and other entrepreneurs. This cycle of creative construction is based on the strategic ability of entrepreneurs in using knowledge spillovers for introducing innovations on the markets (Audretsch and Fritsch, 1996).

Thus, economic perspective can be extended by managerial perspectives on entrepreneurship able to push creative destruction versus a creative construction circle. The theoretical framework we offer here explains the transition process from the latent to emergent entrepreneurship that combines the macroeconomic literature with managerial perspective on knowledge spillover. It evidences the role of entrepreneurship as conduit of change in turning knowledge spillovers in economic knowledge according to knowledge spillover theory of entrepreneurship. This work also recognizes the role of entrepreneur as agent that uses its strategic capabilities to implement activities able to turn latent into emergent entrepreneurship.

\section{References}

Acs Z.J., Audretsch D.B. and Feldman M.P., 1994, R\&D Spillovers and Recipient Firm Size, Review of Economics and Statistics, 100(2), 336-367.

Acs Z.J., Storey D.J. (2004), Introduction: Entrepreneurship and Economic Development, Regional Studies 38(8), 871-877.

Acs Z.J., Varga A. (2005), Entrepreneurship, Agglomeration and Technological Change, Small Business Economics 24(3), 323-334.

Agarwal R., Audretsch D.B., Sarkar M.B. (2007). The process of creative construction: knowledge spillovers, entrepreneurship, and economic growth. Strategic Entrepreneurship Journal 1(3/4): 263286.

Agarwal R., Echambadi R., Franco A.M., Sarkar M. (2004). Knowledge transfer through inheritance: spin-out generation, development, and performance. Academy of Management Journal, 47: 501-522. Agarwal, R., Audretsch, D., Sarkar, M. B. (2010). Knowledge spillovers and strategic entrepreneurship. Strategic Entrepreneurship Journal, 4(4), 271-283. 
Ahuja G., Katila R. (2001). Technological acquisitions and the innovation performance of acquiring firms: a longitudinal study. Strategic Management Journal 22(3): 197-220.

Almeida P., Kogut B. (1999). Localization of knowledge and the mobility of engineers in regional networks. Organization Science, 45: 905-917.

Alvarez S.A., Barney J.B. (2005). How do entrepreneurs organize firms under conditions of uncertainty? Journal of Management, 31: 776-793.

Audretsch D.B., Caiazza R., 2016, Technology transfer and entrepreneurship: Cross-national analysis, The Journal of Technology Transfer vol. 41, N. 6

Audretsch D.B., Lehmann E. (2016), The Seven Secrets of Germany: Economic Resilience in an Era of Global Turbulence (Oxford: Oxford University Press).

Audretsch, D. B. (1995). Innovation and industry evolution. Mit Press.

Audretsch, D. B., Fritsch, M. (1996). Creative destruction: Turbulence and economic growth in Germany. Behavioral Norms, Technological Progress, and Economic Dynamics, 137-150.

Audretsch, D. B., Keilbach, M. (2007). The theory of knowledge spillover entrepreneurship. Journal of Management Studies, 44(7), 1242-1254.

Audretsch, D. B., Belitski, M. (2013). The missing pillar: The creativity theory of knowledge spillover entrepreneurship. Small Business Economics, 41(4), 819-836.

Audretsch, D. B., Keilbach, M. C., Lehmann, E. E. (2006). Entrepreneurship and economic growth. Oxford University Press.

Autio E., Kenney M., Mustar P., Siegel D., Wright M. (2014), Entrepreneurial Innovation: The importance of Context, Research Policy, 43(7), 1097-1108.

Bhide A. (1994). How entrepreneurs craft strategies that work. Harvard Business Review, 72(2): 150161.

Bruton G.D., Ahlstrom D., Li H.L., (2010), Institutional Theory and Entrepreneurship: Where are we now and where do we need to move in the future? Entrepreneurship Theory and Practice, 34(3), 421440. 
Caiazza R., 2015, Explaining innovation in mature industries: Evidences from Italian SMEs, Technology Analysis \& Strategic Management, vol. 27, N. 8, pp. 975-985

Caiazza R., 2016a, A cross-national analysis of policies effecting innovation diffusion, The Journal of Technology Transfer vol. 41, N. 6

Caiazza R., 2016b, Internationalization of SMEs in high potential markets, Trends in Food Science \& Technology

Caiazza R., 2017, Innovation for sustainability: A conceptual framework, Journal of Management Development, vol. 36 issue 1

Caiazza R., Richardson A., Audretsch D.B., 2015, Knowledge effects on competitiveness: From firms to regional advantage, The Journal of Technology Transfer, vol. 40, N. 6, pp. 899-909

Caiazza, R, 2014. Benchmarking of business incubators. Benchmarking: An International Journal, Vol. 21 N. 6, pp. 1062-1069

Caiazza, R., Stanton, J., 2016 The effect of strategic partnership on innovation: An empirical analysis, Trends in Food Science \& Technology, vol. 54, pp. 208-212

Caiazza R., Foss N., Volpe T. 2016b, What we do know and what we need to know about knowledge in the growth process, Journal of Organizational Effectiveness: People and Performance, Volume 3 Issue 2, Pages 191-203

Cohen W., Levinthal D. (1990). Absorptive capacity: a new perspective on learning and innovation. Administrative Science Quarterly, 35: 128-152.

Fleming L. (2001). Recombinant uncertainty in technological search. Management Science, 47: 117132.

Fritsch M. (1997), New Firms and Regional Employment Change, Small Business Economics, 9(5), 437-448.

Fritsch, M., Mueller, P. (2004). Effects of new business formation on regional development over time. Regional Studies, 38(8), 961-975. 
Fritsch, M., Mueller, P. (2008). The effect of new business formation on regional development over time: the case of Germany. Small Business Economics, 30(1), 15-29.

Gambardella A., Giarratana S. (2010). Localized knowledge spillovers and skill-biased performance. Strategic Entrepreneurship Journal, 4(4).

George G., Zahra S.A. (2002). Culture and its consequences for entrepreneurship. Entrepreneurship theory and practice, 26(4), 5-8.

Ireland R.D., Hitt M.A., Sirmon D.G. (2003). A model of strategic entrepreneurship: the construct and its dimensions. Journal of Management 29(6): 963-989.

Kirzner, I. M. (1999). Creativity and/or alertness: A reconsideration of the Schumpeterian entrepreneur. The Review of Austrian Economics, 11(1-2), 5-17.

Kuratko D.F., Audretsch D.B. (2009). Strategic entrepreneurship: exploring different perspectives of an emerging concept. Entrepreneurship Theory and Practice 33: 1-17.

Liu X., Wright M., Filatotchev I., Dai O., Lu J. (2010). Human mobility and international knowledge spillovers: evidence from high-tech small and medium enterprises in an emerging market. Strategic Entrepreneurship Journal 4(4).

Markuerkiaga L., Caiazza R., Igartua J.I., Errasti N., 2016, Factors fostering students’ spin-off firm formation: An empirical comparative study of universities from North and South Europe, Journal of Management Development, vol. 35, N. 6

Marshall, A. (1920). Principles of economics (8th ed.). London: Macmillan.

Mintzberg H., 1978, Patterns in Strategy Formation, Management Science, Vol. 24, No. 9, pp. 934948.

Oldroyd J., Silvestri L., Gulati R. (2010). A learning perspective on intraorganizational knowledge spill-ins. Strategic Entrepreneurship Journal 4(4). 13

Parker S. (2009). The Economics of Entrepreneurship, Cambridge: Cambridge University Press.

Parker S. (2010). A predator-prey model of knowlede spillovers and entrepreneurship. Strategic Entrepreneurship Journal 4(4). 
Porter, 1996, What is strategy? Harvard Business Review, November-December Vol. 74 Issue 6

Romer P.M. (1990). Endogenous technological change. Journal of Political Economy 98: 71-102.

Schumpeter, J.A. 1934. The Theory of Economic Development: An Inquiry into Profits, Capital, Credit, Interest and the Business Cycle. London: Oxford University Press.

Shane S., Venkataraman S. (2000). The Promise of Entrepreneurship as a Field of Research, Academy of Management Review, 25 (1), 217-226.

Spigel, B., Harrison, R. (2018). Toward a process theory of entrepreneurial ecosystems. Strategic Entrepreneurship Journal, 12(1), 151-168.

Stam, E. (2018). Measuring entrepreneurial ecosystems. In Entrepreneurial Ecosystems, Springer, Cham.

Stuart T.E., Sorenson O. (2003), Liquidity Events and the Geographic Distribution of Entrepreneurial Activity, Administrative Science Quarterly, 48 (2), 175-201.

Van Stel A., Carree M., Thurik R. (2005), The Effect of Entrepreneurial Activity on National Economic Growth, Small Business Economics 24(3), 311-321.

Wennekers A.R.M., Van Stel A.J., Thurik A.R., Reynolds P.D. (2005), Nascent Entrepreneurship and the Level of Economic Development, Small Business Economics 24(3), 293- 309

Wennekers S., Thurik A.R. (1999), Linking Entrepreneurship and Economic Growth, Small Business Economics, 13(1), 27-56.

Wiklund J., Davidsson P., Audretsch D.B., Karlsson C. (2011), The Future of Entrepreneurship Research, Entrepreneurship Theory \& Practice, 35 (1), 1-9. 